\title{
Pengaruh Belanja Modal, Pendapatan Asli Daerah Dan Dana Alokasi Umum Terhadap Kinerja Keuangan Dengan Pengawasan Sebagai Variabel Moderating Di Kabupaten/Kota Provinsi Riau Tahun 2014 - 2018
}

\author{
Nora Angelina, Yulia Efni, M. Rasuli \\ Program Magister Manajemen Pasca Sarjana Universitas Riau, Pekanbaru, Indonesia
}

\begin{abstract}
ABSTRAK : Penelitian ini bertujuan untuk melihat dan Pengaruh Belanja Modal, Pendapatan Asli Daerah dan Dana Alokasi Umum Terhadap Kinerja Keuangan Dengan Pengawasan Sebagai Variabel Moderating Di Kabupaten/Kota Provinsi Riau Tahun 2014 - 2018. Populasi dalam penelitian ini adalah kinerja keuangan daerah yang ada di Provinsi Riau sebanyak 12 (dua belas) Kabupaten/Kota selama tahun 2014 - 2018. Metode pengambilan sampel menggunakan metode sensus atau sampel jenuh, yaitu seluruh populasi menjadi sampel penelitian sehingga total sampel yang digunakan dalam penelitian ini adalah 60. Hasil dalam penelitian ini bahwa belanja modal, pendapatan asli daerah dan dana alokasi umum berpengaruh positif signifikan terhadap kinerja keuangan daerah. Pengawasan berpengaruh positif signifikan terhadap kinerja keuangan. Pengawasan dapat memoderasi antara belanja modal, pendapatan asli daerah dan dana alokasi umum dan kinerja keuangan daerah
\end{abstract}

Kata Kunci: Belanja Modal, Pendapatan Asli Daerah, Dana Alokasi Umum, Kinerja Keuangan Daerah dan Pengawasan

\begin{abstract}
This study aims to see and the effect of capital expenditure, local revenue and general allocation funds on financial performance with supervision as a moderating variable in regencies / cities of Riau Province in 2014-2018. The population in this study is the regional financial performance in Riau Province as much as 12 (twelve) Districts / Cities during 2014 2018. The sampling method used the census method or saturated samples, namely the entire population became the research sample so that the total sample used in this study was 60. The results in this study are that capital expenditures, local revenue and general allocation funds have a significant positive effect on regional financial performance. Supervision has a significant positive effect on financial performance. Supervision can moderate between capital expenditures, local revenue and general allocation funds and regional financial performance.
\end{abstract}

Keywords: Capital Expenditures, Regional Original Income, General Allocation Funds, Regional Financial Performance and Supervision

Email Address : noraangelina@gmail.com 


\section{PENDAHULUAN}

Otonomi daerah merupakan suatu kebebasan yang dimiliki daerah untuk membuat peraturan daerah, menyusun dan melaksanakan kebijakan, serta mengelola keuangan daerahnya secara mandiri (Sujarweni, 2015:231). Penerapan kebijakan otonomi daerah menyebabkan daerah agar mampu menggali dan mengembangkan potensi-potensi yang dimiliki daerah. Salah satu untuk mengukur kinerja keuangan daerah dalam penelitian ini adalah dengan cara memakai rasio kemandirian yang digambarkan melalui tingkat ketergantungan daerah terhadap sumber dana ekstern. Rasio kemandirian keuangan daerah (otonomi fiskal) menunjukkan kemampuan pemerintah daerah dalam membiayai sendiri kegiatan pemerintahan, pembangunan, dan pelayanan kepada masyarakat yang telah membayar pajak dan retribusi sebagai sumber pendapatan daerah yang berasal dari sumber lain, misalnya bantuan pemerintah pusat ataupun dari pinjaman. Kemandirian keuangan daerah ditunjukkan oleh besar kecilnya Pendapatan Asli Daerah (PAD) dibandingkan dengan pendapatan daerah yang berasal dari sumber lain, misalnya bantuan pemerintah pusat ataupun dari pinjaman. Rasio kemandirian bertujuan untuk menggambarkan ketergantungan daerah terhadap sumber dana eksternal dan menggambarkan tingkat partisipasi masyarakat dalam pembangunan daerah (Halim, 2014:233). Berikut data tabel 1.1 kinerja keuangan yang dilihat dari rasio kemandirian dari tahun 2014-2018 :

Tabel 1 : Data kinerja keuangan di ukur dengan rasio kemandirian Daerah Kabupaten/Kota se-Provinsi Riau Tahun 2014 - 2018

\begin{tabular}{|c|c|c|c|c|c|}
\hline \multirow{2}{*}{ Kab/Kota } & \multicolumn{5}{|c|}{ Kinerja Keuangan Rasio Kemandirian } \\
\hline & 2014 & 2015 & 2016 & 2017 & 2018 \\
\hline Kuantan Singingi & 4,56 & 6,12 & 5,49 & 8,97 & 6,18 \\
\hline Indragiri Hulu & 7,38 & 10,42 & 7,63 & 12,21 & 8,53 \\
\hline Indragiri Hilir & 6,21 & 8,47 & 7,77 & 13,48 & 9,53 \\
\hline Pelalawan & 6,20 & 9,07 & 8,25 & 14,16 & 10,65 \\
\hline Siak & 13,26 & 24,09 & 11,15 & 19,11 & 14,10 \\
\hline Kampar & 7,59 & 11,25 & 8,18 & 16,76 & 11,50 \\
\hline Rokan Hulu & 6,72 & 7,05 & 7,10 & 18,10 & 6,39 \\
\hline Bengkalis & 6,80 & 10,67 & 7,43 & 9,34 & 10,50 \\
\hline Rokan Hilir & 3,74 & 7,29 & 6,30 & 12,57 & 6,89 \\
\hline Kepulauan Meranti & 5,64 & 6,56 & 5,37 & 9,23 & 6,97 \\
\hline Pekanbaru & 22,95 & 31,27 & 31,20 & 47,31 & 38,34 \\
\hline Dumai & 14,65 & 20,27 & 24,90 & 31,60 & 30,75 \\
\hline $\bar{X}$ & 8,81 & 12,71 & 10,90 & 17,74 & 13,36 \\
\hline $\begin{array}{ll}\text { Keterangan : } \\
\text { 1. Tinggi } 75 \% \\
\text { 2. Sedang } 50 \% \\
\text { 3. Rendah } 25 \% \\
\text { 4. } \\
\text { Rendah sek }\end{array}$ & $\begin{array}{l}\% \\
6 \\
6 \\
\% \\
0-25 \%\end{array}$ & & & & \\
\hline
\end{tabular}

Sumber : BPKAD Provinsi Riau, 2020.

Dari Tabel 1.1 menunjukkan bahwa kinerja keuangan pemerintah daerah kabupaten/kota se-Provinsi Riau periode tahun 2014 s.d. 2018 yang di ukur dengan rasio kemandirian sangat rendah sekali karena tidak ada satupun kabupaten/kota yang rasio kemandirianya melebihi $50 \%$. Hal ini tentunya akan berpengaruh terhadap pertumbuhan dan pembangunan suatu daerah dimana sangat 
ketergantungannya pemerintah daerah terhadap sumber dana luar atau eksternal. Rasio kemandirian menggambarkan ketergantungan daerah terhadap sumber dana eksternal. Semakin tinggi rasio kemandirian mengandung arti bahwa tingkat ketergantungan daerah terhadap bantuan pihak eksternal (terutama pemerintah pusat dan propinsi) semakin rendah, dan demikian pula sebaliknya. Rasio kemandirian juga menggambarkan tingkat pertisipasi masyarakat dalam membayar pajak dan retribusi daerah yang merupakan komponen utama pendapatan asli daerah. Semakin tinggi masyarakat membayar pajak dan retribusi daerah akan menggambarkan tingkat kesejahteraan masyarakat yang semakin tinggi.

Salah satu faktor terjadinya kinerja keuangan daerah yang baik dari sisi belanja modalnya. Belanja modal merupakan suatu pengeluaran yang dapat dikatakan sebagai pengeluaran rutin dalam rangka pembentukkan modal yang ada. Belanja modal adalah suatu pengeluaran yang dilakukan untuk menambah aset tetap atau investasi yang ada sehingga akan memberikan manfaat tersendiri pada periode tertentu. Dalam hal tersebut masuk ke dalam pembukuan akuntansi, dengan kata lain belanja modal akan mempengaruhi posisi keuangan. Rasio belanja modal terhadap total belanja daerah mencerminkan porsi belanja daerah yang dibelanjakan untuk belanja modal. Belanja modal ditambah belanja operasi, merupakan belanja pemerintah yang diharapkan memiliki pengaruh signifikan terhadap pertumbuhan ekonomi suatu daerah, selain dari sektor swasta, rumah tangga, dan luar negeri. Oleh karena itu, semakin tinggi angka rasionya, semakin baik pengaruhnya terhadap pertumbuhan ekonomi. Sebaliknya, semakin rendah angkanya, semakin buruk pengaruhnya terhadap pertumbuhan ekonomi. Realisasi belanja modal daerah kabupaten/kota seProvinsi Riau untuk periode tahun 2014 2018 disajikan pada tabel 1.2 sebagai berikut:

Tabel 2 : Realisasi Belanja Modal Daerah Kabupaten/Kota se-Provinsi Riau Tahun 2014 - 2018

\begin{tabular}{|l|c|c|c|c|c|}
\hline \multirow{2}{*}{ Kab/Kota } & \multicolumn{6}{|l|}{ Realisasi Belanja Modal (Milyar rupiah) } \\
\cline { 2 - 6 } & $\mathbf{2 0 1 4}$ & $\mathbf{2 0 1 5}$ & $\mathbf{2 0 1 6}$ & $\mathbf{2 0 1 7}$ & $\mathbf{2 0 1 8}$ \\
\hline Kuantan Singingi & 358,43 & 326,74 & 178,02 & 203,27 & 196,80 \\
\hline Indragiri Hulu & 557,61 & 320,88 & 246,98 & 247,69 & 138,09 \\
\hline Indragiri Hilir & 394,04 & 358,40 & 415,38 & 353,14 & 213,66 \\
\hline Pelalawan & 327,48 & 453,58 & 454,68 & 254,67 & 161,28 \\
\hline Siak & $1.005,35$ & $1.005,35$ & 252,76 & 216,46 & 179,48 \\
\hline Kampar & 624,43 & 490,40 & 377,69 & 352,06 & 315,56 \\
\hline Rokan Hulu & 330,67 & 279,25 & 252,87 & 330,43 & 353,29 \\
\hline Bengkalis & $1.316,32$ & $1.815,70$ & 765,74 & 982,28 & 903,41 \\
\hline Rokan Hilir & 561,19 & 465,85 & 399,64 & 339,74 & 217,56 \\
\hline $\begin{array}{l}\text { Kepulauan } \\
\text { Meranti }\end{array}$ & 289,13 & 196,50 & 255,39 & 173,84 & 169,80 \\
\hline Pekanbaru & 647,10 & 821,63 & 450,34 & 466,57 & 531,15 \\
\hline Dumai & 383,17 & 143,89 & 200,12 & 272,62 & 174,22 \\
\hline Jumlah & $\mathbf{6 . 7 9 4 , 9 1}$ & $\mathbf{6 . 6 7 8 , 1 7}$ & $\mathbf{4 . 2 4 9 , 6 1}$ & $\mathbf{4 . 1 9 2 , 7 7}$ & $\mathbf{3 . 5 5 4 , 3 1}$ \\
\hline $\bar{X}$ & $\mathbf{5 6 6 , 2 4}$ & $\mathbf{5 5 6 , 5 1}$ & $\mathbf{3 5 4 , 1 3}$ & $\mathbf{3 4 9 , 4 0}$ & $\mathbf{2 9 6 , 1 9}$ \\
\hline
\end{tabular}

Sumber : BPKAD Provinsi Riau, 2020.

Dari Tabel 2 menunjukkan bahwa kecenderungan belanja modal pemerintah daerah kabupaten/kota se-Provinsi Riau periode tahun 2014 s.d. 2018, secara 
umum dari tahun ke tahun mengalami fluktuasi dalam belanja modal. Rata-rata realisasi belanja modal pemerintah daerah kabupaten/kota se-Provinsi Riau tertinggi pada tahun 2014 sebesar 566, 24 milyar rupiah dan terendah pada tahun 2018 sebesar 296,19 milyar rupiah. Pentingnya belanja Modal dikarenakan belanja modal pemerintah daerah akan bermanfaatnya melebihi satu tahun anggaran dan akan menambah aset atau kekayaan daerah dan selanjutnya akan menambah belanja yang bersifat rutin seperti biaya pemeliharaan pada kelompok belanja operasi. Kelompok belanja ini mencakup jenis belanja baik untuk bagian belanja pegawai maupun pelayanan publik sehingga semakin besarnya belanja modal yang diberikan maka akan semakin baik dalam peningkatan kinerja keuangan.

Faktor lainnya yang mempengaruhi kinerja keuangan daerah adalah pendapatan asli daerah itu sendiri. Pendapatan asli daerah merupakan komponen yang sangat penting dalam daerah karena digunakan untuk membiayai segala program-program yang direncanakan oleh pemerintah daerah yang bertujuan untuk meningkatkan kesejahteraan masyarakat dan perekonomian daerah (Mohammed et al., 2015). Menurut Undang-Undang Republik Indonesia Nomor 23 Tahun 2014, pendapatan daerah merupakan seluruh penerimaan daerah yang bersumber dari beberapa komponen dan mampu menambah nilai kekayaan bersih yang dimiliki daerah. Pertumbuhan pendapatan daerah mengalami kenaikan atau penurunan tergantung dari seberapa besar sumber-sumber keuangan daerah mampu menghasilkan pendapatan bagi daerahnya. Pemerintah Daerah harus dapat meningkatkan pendapatan asli daerah tanpa harus melanggar norma-norma dengan cara mengoptimalisasi potensi yang ada. Optimalisasi pendapatan asli daerah dari sisi penerimaan hendaknya diikuti dengan pengelolaan penggunaan anggaran dari sisi pengeluaran dan dikelola dengan baik dengan prinsip value for money serta dilakukan secara komprehensif dengan berbagai strategi sesuai dengan kaidah pengelolaan keuangan daerah dan keuangan negara, dengan peningkatan prosedur pengendalian dari intern pemerintah daerah agar terpenuhi prinsip stewardship dan accountability.

Selain faktor belanja modal dan pendapatan asli daerah, faktor dana alokasi umum juga mempengaruhi kinerja keuangan dimana dana alokasi umum adalah bagian dari Dana Perimbangan yang diberikan setiap tahunnya yang diambil dari dana APBN, dan besarnya dana yang diberikan tersebut ditentukan oleh kebutuhan daerah dan potensi daerahnya masing-masing. Alokasi tersebut bertujuan untuk pemerataan kemampuan keuangan antar daerah, mendanai kebutuhan daerah dalam rangka pelaksanaan desentralisasi. Dana Alokasi Umum tersebut dialokasikan dalam bentuk block grant, dimana penggunaannya diserahkan sepenuhnya kepada daerah. Sesuai dengan prioritas dan kebutuhan daerah untuk peningkatan pelayanan kepada masyarakat dalam rangka pelaksanaan otonomi daerah.

Alokasi Dana Alokasi Umum bersifat dinamis sesuai dengan capaian pendapatan dalam negeri tersebut. Besaran alokasi Dana Alokasi Umum per daerah dihitung menggunakan formulasi yang tertuang dalam Undang-Undang Nomor 33 Tahun 2004 dan Peraturan Pemerintah Nomor 55 Tahun 2005. Menteri Keuangan Sri Mulyani mengatakan idealnya skema Dana Alokasi Umum bersifat dinamis, sebab penerimaan pendapatan negara yang menjadi sumber Dana Alokasi Umum pun sifatnya tidak tetap. Menurutnya, pemerintah pusat bekerja keras untuk memastikan penerimaan bisa akurat dengan proyeksi dan estimasi. Maka, pemerintah daerah harus memberi upaya demikian untuk memastikan penerimaan dalam APBD-nya.

Menurut PP No. 55 Tahun 2005 Dana Alokasi Umum adalah dana yang bersumber dari pendapatan APBN yang dialokasikan dengan tujuan pemerataan kemampuan keuangan antar daerah untuk 
mendanai kebutuhan daerah dalam rangka pelaksanaan desentralisasi. Proporsi dalam dana alokasi umum antara provinsi dan kabupaten/kota dihitung dari perbandingan antara bobot urusan pemerintahan yang menjadi kewenangan provinsi dan kabupaten/kota. Proporsi ini ditetapkan dengan imbangan 10\% (sepuluh persen) untuk provinsi dan $90 \%$ (sembilan puluh persen) untuk kabupaten/kota. Jumlah dana alokasi umum bagi semua daerah provinsi tersebut dan jumlah daerah bagi semua daerah kabupaten/kota masing-masing ditetapkan setiap tahun dalam APBN. Dana alokasi umum yang dimaksud ini merupakan jumlah semua dana alokasi umum untuk daerah provinsi dan untuk daerah kabupaten/kota. Perubahan dana alokasi umum akan sejalan dengan penyerahan dan pengalihan kewenangan pemerintah pusat kepada daerah dalam rangka desentralisasi.

Dari ketiga faktor belanja modal, pendapatan asli daerah dan dana alokasi umum yang mempengaruhi kinerja keuangan perlu adanya pengawasan yang baik untuk memonitoring agar kinerja keuangan tepat sasaran. Karena pengawasan keuangan daerah berkaitan erat dengan kinerja pemerintah daerah. Hal ini disebabkan karena pencapaian keberhasilan suatu visi dan misi membutuhkan pengawasan yang baik dan maksimal, baik dalam segi perencanaan, penganggaran, dan pelaksanaan kegiatan yang telah direncanakan sebelumnya. Dalam penelitian ini mengambil pengawasan di internal, salah satunya adalah Inspektorat Daerah yang mempunyai fungsi perencanaan program pengawasan, perumusan kebijakan dan fasilitasi pengawasan, pemeriksaan, pengusutan, pengujian dan penilaian tugas pengawasan, pemeriksaan serta pelaksanaan tugas lain yang diberikan oleh Kepala Dearah dibidang pengawasan. Fungsi dan tugas inspektorat di daerah seharusnya diperluas, meliputi pengawasan pelaksanaan pelayanan publik di daerah, pengawasan internal pada OPD tidak hanya pada fungsi pengawasan anggaran, sebaiknya diperluas sehingga pengaduan masyarakat dapat ditangani secara internal dan dilakukan pengawasan langsung oleh inspektorat.

Pengawasan Intern adalah seluruh proses kegiatan audit, reviu, evaluasi, pemantauan, dan kegiatan pengawasan lain terhadap penyelenggaraan tugas dan fungsi organisasi dalam rangka memberikan keyakinan yang memadai bahwa kegiatan telah dilaksanakan sesuai dengan tolok ukur yang telah ditetapkan secara efektif dan efisien untuk kepentingan pimpinan dalam mewujudkan tata kepemerintahan yang baik. Salah satu faktor utama yang dapat menunjang keberhasilan pelaksanaan pengendalian Intern adalah efektivitas peran Aparat Pengawasan Intern Pemerintah (APIP). Untuk itu, APIP harus terus melakukan perubahan dalam menjalankan proses bisnis guna memberi nilai tambah bagi kementerian negara/lembaga dan penyelenggaraan pemerintahan daerah. Beberapa penelitian sebelumnya juga meneliti mengenai pengaruh pendapatan asli daerah terhadap kinerja keuangan pemerintah daerah.

Penelitian Aprilia dan Addirfa (2016) memberikan hasil belanja modal berpengaruh positif signifikan terhadap kinerja keuangan daerah. Bertentangan dengan hasil penelitian yang dilakukan oleh Malendra (2016), bahwa belanja modal tidak berpengaruh signifikan terhadap kinerja keuangan daerah. Pada sisi lain penelitian yang dilakukan Mulyani dan Wibowo (2017) mendapatkan hasil bahwa pendapatan asli daerah berpengaruh negatif signifikan terhadap kinerja keuangan pemerintah daerah yang memberikan indikasi bahwa peningkatan pendapatan asli daerah dapat menurunkan kinerja keuangan pemerintah daerah. Penelitian yang dilakukan oleh Faisal dan Nofrianto (2016), menemukan bahwa dana alokasi umum berpengaruh positif signifikan terhadap kinerja keuangan pemerintah daerah. sunaryo dan Gofar (2015), menemukan bahwa dana alokasi umum tidak berpengaruh positif signifikan terhadap kinerja keuangan pemerintah daerah. Penelitian yang dilakukan oleh 
Fahmi dan Addirfa (2015) memberikan hasil pengawasan berpengaruh positif signifikan terhadap kinerja keuangan daerah. Sejalan dengan hasil penelitian yang dilakukan oleh Irawan (2014), bahwa pengawasan berpengaruh positif signifikan terhadap kinerja keuangan daerah.

Penelitian ini merupakan replikasi dari beberapa penelitian yang telah dilakukan sebelumnya. Akan tetapi ada beberapa perbedaan diantaranya yaitu: (1) Dalam penelitian ini peneliti menambahkan variabel pengawasan sebagai moderasi yang tidak ada pada penelitian sebelumnya, dimana pengawasan sangat penting untuk melihat keberhasilan suatu daerah dalam rangka meningkatkan kinerja keuangan yang transparansi dan akuntabilitas. (2) Pada objek penelitian dimana dalam penelitian ini objek penelitiannya yaitu pada 12 daerah Kabupaten/Kota di Provinsi Riau, hal ini peneliti lakukan karena dari pengamatan awal ditemukan bahwa Kinerja Keuangan pada 12 daerah Kabupaten/Kota di Provinsi Riau cenderung sangat rendah yang berbanding terbalik dengan PAD, DAU dan Belanja Modal yang justru mengalami fluktuatif sehingga menjadi menarik untuk diteliti bagaimana sebenarnya dan seberapa besar pengaruh dari PAD, DAU, dan Belanja Modal tersebut dapat mempengaruhi Kinerja Keuangan. (3) Periode pengamatan, dimana periode pengamatan yang digunakan pada penelitian ini, lebih up to date yaitu selama lima tahun dari tahun 2014 sampai dengan tahun 2018.

\section{TINJAUAN}

\subsection{Teori Stewardship}

Ilmu atau teori yang di gunakan dalam metode pembelajaran Akuntansi Sektor Publik adalah menggunakan teori Stewardship. Teori stewardship (pengabdian) berpendapat bahwa sebenarnya manusia pada hakikatnya mampu bertindak dengan penuh tanggung jawab, berintegritas tinggi, memiliki kejujuran serta dapat dipercaya. Teori stewardship memandang manajemen sebagai pihak yang mampu menjalankan tindakan dengan sangat baik yang berfungsi untuk memenuhi kebutuhan stakeholders. Teori ini adalah sebagai dasar teori yang menyatakan bahwa teori ini tidak memiliki keinginan untuk memenuhi kepentingan pribadi sebagai bentuk dan upaya untuk menghindari konflik dengan stakeholders. "Teori stewardship dapat berfungsi sebagai mekanisme pertanggungjawaban untuk dapat memastikan pemantauan, audit dan pelaporan yang baik agar dapat membantu pencapaian tujuan organisasi (Jefri, 2018)".

\subsection{Kinerja Keuangan (Rasio Kemandirian)}

Sebagaimana yang tercantum dalam Undang-undang Nomor 32 tahun 2004 bahwa "kemandirian keuangan daerah berarti pemerintah dapat melakukan pembiayaan dan pertanggungjawaban keuangan sendiri, melaksanakan sendiri, dalam rangka asas desentralisasi”. Pengertian kemandirian keuangan daerah dikemukakan oleh Halim (2008:232) sebagai berikut: "Kemandirian keuangan daerah adalah kemampuan pemerintah daerah dalam membiayai sendiri kegiatan pemerintahan, pembangunan, dan pelayanan kepada masyarakat yang telah membayar pajak dan retribusi sebagai sumber pendapatan yang diperlukan daerah."

\subsection{Belanja Modal}

Menurut PP Nomor 71 Tahun 2010, belanja modal adalah pengeluaran anggaran untuk perolehan aset tetap dan aset lainnya yang memberi manfaat lebih dari satu periode akuntansi. Belanja modal meliputi antara lain belanja modal untuk perolehan tanah, gedung dan bangunan, peralatan, aset tak berwujud. Belanja modal digunakan untuk memperoleh aset tetap pemerintah daerah seperti peralatan, infrastruktur, dan aset tetap lainnya. Cara 
mendapatkan belanja modal dengan membeli melalui proses lelang atau tender.

\subsection{Pendapatan Asli Daerah}

Berdasarkan penjelasan dari UU No. 33 Tahun 2004 Pendapatan Asli Daerah (PAD) adalah salah satu sumber dana pembiayaan pembangunan daerah pada kenyataannya belum cukup memberikan sumbangan bagi pertumbuhan daerah, hal ini mengharuskan pemerintah daerah menggali dan meningkatkan pendapatan daerah terutama sumber pendapatan asli daerah. Pendapatan Asli Daerah (PAD) merupakan pendapatan daerah yang bersumber dari hasil pajak daerah, hasil retribusi daerah, hasil pengelolaan kekayaan daerah yang dipisahkan, dan lain-lain pendapatan asli daerah yang sah, yang bertujuan untuk memberikan keleluasaan kepada daerah dalam menggali pendanaan dalam pelaksanaan otonomi daerah sebagai perwujudan asas desentralisasi.

\subsection{Dana Alokasi Umum}

Menurut Undang-Undang Nomor 33 Tahun 2004 tentang Perimbangan Keuangan Pusat dan Keuangan Daerah disebutkan bahwa "Dana Alokasi Umum adalah dana yang bersumber dari pendapatan APBN yang dialokasikan dengan tujuan pemerataan kemampuan keuangan antar daerah untuk mendanai kebutuhan daerah dalam pelaksanaan desentralisasi". Menurut Awaniz (2011: 19) "Dana alokasi umum merupakan jenis transfer dana antar tingkat pemerintahan yang tidak terikat dengan program pengeluaran tertentu".

\section{DATA DAN METODOLOGI}

\subsection{Lokasi dan Waktu Penelitian}

Lokasi dalam penelitian ini dilakukan pada seluruh Kabupaten / Kota di Provinsi Riau selama periode tahun 2014 - 2018. Jenis data yang digunakan dalam penelitian ini merupakan data kuantitatif yaitu berupa laporan keuangan pada tahun 2014 - 2018 yang diperoleh dari Badan Pengelola Keuangan dan Aset Daerah (BPKAD) Provinsi Riau.

\subsection{Populasi dan Sampel}

Populasi dalam penelitian ini adalah kinerja keuangan daerah yang ada di Provinsi Riau sebanyak 12 (dua belas) Kabupaten/Kota selama tahun 2014 2018. Sampel merupakan bagian populasi yang akan diteliti atau sebagian jumlah dari karakteristik yang dimiliki oleh populasi. Dikarenakan pada jumlah populasi yang tidak terlalu banyak, maka penulis mengambil keseluruhan populasi sebagai sampel. Metode pengambilan sampel menggunakan metode sensus atau sampel jenuh, yaitu seluruh populasi menjadi sampel penelitian sehingga total sampel yang digunakan dalam penelitian ini adalah 60 .

\subsection{Analisis Statistik Deskriptif}

Analisis statistik deskriptif merupakan teknik deskriptif yang memberikan informasi mengenai data yang dimiliki dan tidak bermaksud menguji hipotesis. Analisis ini hanya digunakan untuk menyajikan dan menganalisis data disertai dengan perhitungan agar dapat memperjelas keadaan atau karakteristik data yang bersangkutan. Pengukuran yang digunakan dalam penelitian ini adalah mean, standar deviasi, maksimum, dan minimum. Mean digunakan untuk mengetahui rata-rata data yang bersangkutan

\subsection{Uji Normalitas}

Uji normalitas merupakan suatu pengujian yang bertujuan untuk mengetahui apakah dalam model regresi, variabel pengganggu atau residual memiliki distribusi normal 
atau tidak. Pengujian normalitas distribusi data populasi dilakukan dengan menggunakan statistik KolmogorovSmirnov. Data populasi dikatakan berdistribusi normal jika koefisien Asymp. Sig (2-tailed) lebih besar dari $\alpha=0.05$.

\subsection{Moderated Regression Analysis}

Uji interaksi atau sering disebut dengan Moderated Regression Analysis (MRA) merupakan aplikasi khusus regresi linear berganda dimana dalam persamaan regresinya mengandung unsur interaksi (perkalian dua atau lebih variabel independen) (Ghozali, 2012). Mengingat model dalam penelitian menggunakan variabel moderasi, maka untuk menguji hipotesis yang diajukan digunakan Moderate Regression Analysis (MRA).

Adapun model persamaan multiple regression analysis dalam penelitian ini adalah sebagai berikut:

$\mathrm{Y}=\alpha+\beta 1 \mathrm{X}_{1}+\beta 2 \mathrm{X}_{2}+\beta 3 \mathrm{X}_{3}+\beta 4 \mathrm{Z}+$ $\beta 5\left[\left\{\mathrm{X}_{1} * \mathrm{Z}\right\}\right]+\beta 6\left[\left\{\mathrm{X}_{2} * \mathrm{Z}\right\}\right]+\beta 7\left[\left\{\mathrm{X}_{3} * \mathrm{Z}\right\}\right]$ $+\varepsilon$

Dimana:

$\mathrm{Y}=$ Kinerja Keuangan

\section{HASIL DAN PEMBAHASAN}

\subsection{Analisis Deskripif Variabel Penelitian}

Tabel 3: Statistik Deskriptif

\begin{tabular}{|l|r|r|r|r|r|}
\hline \multicolumn{7}{|c|}{ Descriptive Statistics } \\
\hline & $\mathrm{N}$ & \multicolumn{1}{|c|}{ Minimum } & Maximum & \multicolumn{1}{c|}{ Mean } & Std. Deviation \\
\hline Kinerja Keuangan & 60 & 3.74 & 47.31 & 12.7028 & 9.09000 \\
\hline Belanja Modal & 60 & 138.09 & 1815.70 & 424.4962 & 307.54190 \\
\hline PAD & 60 & 52.41 & 697.47 & 188.5192 & 134.44953 \\
\hline DAU & 60 & 85.78 & 918.60 & 540.7638 & 202.61986 \\
\hline Pengawasan & 60 & 70.00 & 92.50 & 80.4583 & 7.25579 \\
\hline Valid N (listwise) & 60 & & & & \\
\hline
\end{tabular}

Sumber : Data Olahan 2020

Berdasarkan Tabel 3 dari dapat dilihat bahwa pada variable kinerja keuangan memiliki nilai mean sebesar 12,70 dengan standar deviasi sebesar $\begin{array}{lll}\mathrm{a} & = & \text { Konstanta } \\ \mathrm{X}_{1} & = & \text { Belanja Modal } \\ \mathrm{X}_{2} & = & \text { Pendapatan Asli Daerah } \\ \mathrm{X}_{3} & = & \text { Dana Alokasi Umum } \\ \mathrm{Z} & = & \text { Pengawasan } \\ \mathrm{X}_{1} * \mathrm{Z} & = & \text { Interaksi antara Belanja }\end{array}$ Modal dan Pengawasan.

$\mathrm{X}_{2} * \mathrm{Z}=$ Interaksi antara $\mathrm{PAD}$ dan Pengawasan.

$\mathrm{X}_{3} * \mathrm{Z}=$ Interaksi antara DAU dan Pengawasan

e $=$ Error

\subsection{Uji Koefisien Determinasi $\left(\mathbf{R}^{2}\right)$}

Koefisien Determinasi $\left(\mathrm{R}^{2}\right)$ digunakan untuk mengukur seberapa jauh kemampuan variabel-variabel dependen. Nilai koefisien determinasi $\left(\mathrm{R}^{2}\right)$ adalah antara nol dan satu. Nilai $R^{2}$ yang kecil berarti kemampuan variabel-variabel independen dalam menjelaskan variabel dependen amat terbatas. Jika koefisien determinasi sama dengan nol, maka variabel independen tidak berpengaruh terhadap variabel dependen. 
(PAD) memiliki nilai mean sebesar 188,51 dengan standar deviasi sebesar 134,44 dan Dana Alokasi Umum (DAU) memiliki nilai mean sebesar 540,76 dengan standar deviasi 202,61 sedangkan untuk variable moderasi (pengawasan) memiliki nilai mean sebesar 80,45 dengan standar deviasi sebesar 7,25. Dari hasil statistik deskriptif dari semua variable penelitian dapat terlihat bahwa nilai mean lebih besar dari nilai standar deviasi, hal ini menunjukan bahwa sebaran data yang digunakan cukup baik mengindikasikan data tersebut layak digunakan dalam penelitian ini.

\subsection{Uji Normalitas}

Tabel 4 Uji Normalitas

\begin{tabular}{|c|c|}
\hline \multicolumn{2}{|c|}{ One-Sample Kolmogorov-Smirnov Test } \\
\hline & Unstandar \\
& dized \\
& Residual \\
\hline
\end{tabular}

\subsection{Moderated Regression Analysis}

\begin{tabular}{|l|l|r|}
\hline $\mathrm{N}$ & Mean & 60 \\
\hline \multirow{2}{*}{$\begin{array}{l}\text { Normal } \\
\text { Parameters }\end{array}$} & Std. & .0000000 \\
\hline \multirow{2}{*}{ Most Extreme } & Deviation & 3.2891912 \\
Differences & Absolute & .140 \\
\cline { 2 - 3 } & Positive & .140 \\
\cline { 2 - 3 } & Negative & -.083 \\
\hline Kolmogorov-Smirnov Z & 1.082 \\
\hline Asymp. Sig. (2-tailed) & .192 \\
\hline \multicolumn{2}{|l|}{ a. Test distribution is Normal. } \\
\hline \multicolumn{2}{|l|}{ b. Calculated from data. } \\
\hline
\end{tabular}

Sumber: Data diolah peneliti 2020

Berdasarkan Tabel 4 dari hasil uji normalitas diatas dari semua variabel yang di unstandardized didapat nilai Asymp. Sig. (2-tailed) sebesar $0,192>0,05$ artinya bahwa data yang digunakan dalam penelitian ini berdistribusi normal dan menunjukan model regresi layak untuk dipakai.

Tabel 7 Uji MRA

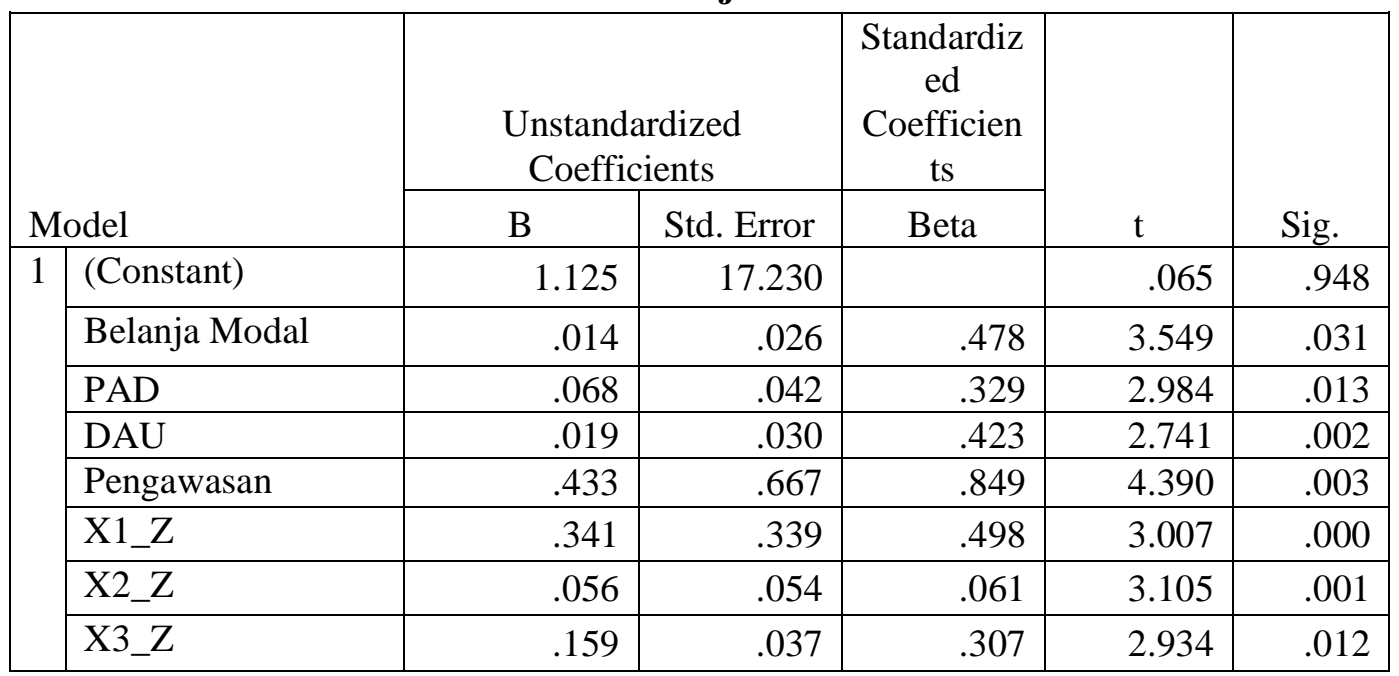

Sumber: Data diolah peneliti, 2020

Berdasarkan Tabel 7 pada model regresi diatas dapat diketahui hubungan antara variabel bebas terhadap variabel terikat yang dapat dirumuskan dalam persamaan sebagai berikut:

$\begin{aligned} \mathrm{Y}_{(\text {Kinerja) }}= & 1,125_{(\alpha)}+0,014_{(\mathrm{X} 1)}+ \\ & 0,068_{(\mathrm{X} 2)}+0,019_{(\mathrm{X} 3)}+\end{aligned}$

$$
\begin{aligned}
& 0,433_{(\mathrm{Z})}+0,341_{(\mathrm{X1Z})}{ }^{-} \\
& 0,056_{(\mathrm{X} 2 \mathrm{Z})}+0,159_{(\mathrm{X} 3 \mathrm{Z})}+\mathrm{e}^{-}
\end{aligned}
$$

\subsection{Uji R Square}

Tabel 410 Koefisien Determinasi

\begin{tabular}{|l|c|c|c|c|}
\hline \multicolumn{5}{|c|}{ Model Summary $^{\mathbf{b}}$} \\
\hline Model & $\mathrm{R}$ & $\mathrm{R}$ & Adjusted & Std. \\
\hline
\end{tabular}




\begin{tabular}{|l|r|r|r|r|}
\hline & & Square & $\begin{array}{c}\text { R } \\
\text { Square }\end{array}$ & $\begin{array}{c}\text { Error of } \\
\text { the } \\
\text { Estimate }\end{array}$ \\
\hline 1 & $.934^{\mathrm{a}}$ & .872 & .855 & 3.45966 \\
\hline \multicolumn{2}{|l|}{$\begin{array}{l}\text { a. Predictors: (Constant), X3_Z, PAD, X1_Z, } \\
\text { Pengawasan, X2_Z, DAU, Belanja Modal }\end{array}$} \\
\hline \multicolumn{2}{|l|}{ b. Dependent Variable: Kinerja Keuangan } \\
\hline
\end{tabular}

Sumber: Data diolah peneliti,

Berdasarkan Tabel 10 nilai adjusted $\mathrm{R}^{2}$ sebesar 0,872. Hasil ini menunjukan bahwa kontribusi variabel bebas dapat menjelaskan variabel terikat sebesar $87,2 \%$ sedangkan sisanya $12,8 \%$ di jelaskan oleh variabel lain yang tidak terdapat didalam penelitian ini.

\subsection{Hasil Pembahasan}

\subsubsection{Pengaruh belanja modal terhadap kinerja keuangan daerah}

Hasil dalam penelitian ini menunjukan belanja modal berpengaruh positif signifikan terhadap kinerja keuangan daerah artinya Belanja modal adalah komponen belanja langsung dalam anggaran pemerintah yang menghasilkan output berupa aset tetap. Dalam pemanfaatan aset tetap yang dihasilkan tersebut, ada yang bersinggungan langsung dengan pelayanan publik atau dipakai oleh masyarakat (seperti jalan, jembatan, trotoar, gedung olah raga, stadion, jogging track, halte, dan rambu lalu lintas) dan ada yang tidak langsung dimanfaatkan oleh publik (seperti gedung kantor pemerintahan). Dalam perspektif kebijakan publik, sebagian besar belanja modal berhubungan dengan pelayanan publik, sehingga pada setiap anggaran tahunan jumlahnya semestinya relatif besar.

Namun, tidak selalu belanja modal berhubungan langsung dengan pelayanan publik. Beberapa proyek fisik menghasilkan output berupa bangunan yang sepenuhnya dinikmati oleh aparatur (birokrasi) atau satuan kerja yang tidak berhubungan langsung dengan fungsi pelayanan publik. Sebagaimana belanja

modal untuk pembangunan kantor Bappeda (Badan Perencanaan Pembangunan Daerah) atau inspektorat daerah. Oleh karena itu, tidak tepat jika dikatakan bahwa belanja modal adalah belanja publik, atau sebaliknya, belanja publik adalah belanja modal. Pengaktegorian ke dalam belanja publik dan belanja aparatur mengandung bias dari aspek penggunaan makna fungsi (outcome) belanja.

Seiring

diselenggarakannya otonomi suatu daerah maka harus dapat mengembangkan daerahnnya sendiri agar kegiatan pemerintah dalam pembangunan daerah dapat terlaksana seperti belanja modal tanah, peralatan dan mesin, gedung dan bangunan, jalan, irigasi dan jaringan, dan modal fisik lainnya. Menurut UU No. 23 tahun 2014 tentang pemerintah daerah dalam proses penyusunan anggaran belanja. Teori stewardship memandang manajemen sebagai pihak yang mampu menjalankan tindakan dengan sangat baik yang berfungsi untuk memenuhi kebutuhan stakeholders. Semakin tinggi tingkat investasi belanja modal yang diharapkan mampu meningkatkan kualitas layanan publik karena Alokasi belanja modal didasarkan pada kebutuhan daerah akan sarana dan prasarana, baik untuk kelancaran pelaksanaan tugas pemerintahan maupun untuk fasilitas publik sehingga kemajuan pertumbuhan ekonomi yang ditandai dengan meningkatnya produktivitas dan pendapatan perkapita penduduk di riau dapat terealisasi dan terjadi perbaikan kesejahteraan. Belanja modal yang besar merupakan cerminan dari banyaknya infrastruktur yang dibangun sehingga meningkatkan kinerja keuangan daerah sesuai dengan angka dan logika, dalam peningkatan capaian dari suatu hasil kerja dibidang keuangan daerah yang meliputi rasio anggaran dan realisasi merupakan indikator yang baik dalam mengukur tingkat pertumbuhan ekonomi suatu daerah. 
Penelitian yang dilakukan oleh Aprilia dan Addirfa (2016) memberikan hasil belanja modal berpengaruh positif signifikan terhadap kinerja keuangan daerah. Bertentangan dengan hasil penelitian yang dilakukan oleh Malendra (2016), bahwa belanja modal tidak berpengaruh signifikan terhadap kinerja keuangan daerah.

\subsubsection{Pengaruh pendapatan asli daerah (PAD) terhadap kinerja keuangan daerah}

Hasil dalam penelitian ini menunjukan pendapatan asli daerah (PAD) berpengaruh positif signifikan terhadap kinerja keuangan daerah artinya dengan semakin baiknya pengelolaan pendapatan asli daerah (PAD) dalam membiayai segala program-program yang direncanakan oleh pemerintah yang bertujuan untuk meningkatkan kesejahteraan masyarakat dan perekonomian daerah sehingga kinerja keuangan daerah semaikin baik. Pendapatan Asli Daerah merupakan semua penerimaan daerah yang berasal dari sumber ekonomi asli daerah. Pertumbuhan ekonomi daerah akan merangsang meningkatnya pendapatan penduduk di daerah yang bersangkutan, seiring dengan meningkatnya pendapatan asli daerah. Semakin besar dana Pendapatan Asli Daerah berarti semakin besar belanja daerah yang dilakukan pemerintah daerah untuk pembangunan di daerahnya masing-masing.

Dalam teori stewardship para pengelola anggaran diharapkan akan bekerja dengan sebaik-baiknya untuk kepentingan principal yaitu masyarakat dan instansi mereka sehingga suatu oragnisasi dapat dipercaya untuk bertindak sesuai dengan kepentingan publik dengan melaksanakan tugas dan fungsinya dengan tepat, merencanakan dan melaksanakan anggaranyang diamanahkan kepadanya, dengan demikian tujuan pengelolaan anggarandapat tercapai secara maksimal. Untuk melaksanakan tanggungjawab tersebut maka stewards diharapkan mengerahkan semua kemampuan dan keahlian Sumber Daya Manusianya dengan memanfaatkan Teknologi Informasi, Komitmen semua pegawai yang terlibat dalam pengelolaan anggaran sehingga diharapkan dapat mencapai pengelolaan anggaran yang makin efektif.

Pemerintah daerah perlu memfasilitas berbagai aktivitas peningkatan perekonomian, salah satunya dengan membuka kesempatan berinvestasi. Pembangunan infrastruktur dan pemberian berbagai fasilitas kemudahan dilakukan untuk meningkatkan daya tarik investasi. Pembangunan infrastruktur industry akan memberikan dampak nyata terhadap kenaikan pendapatan asli daerah (PAD). UU No 17 Tahun 2003 Tentang Keuangan Negara Pasal 31 yang mengatur bahwa Kepala Daerah harus memberikan pertanggungjawaban pelaksanaan APBD kepada DPRD berupa Laporan Keuangan. Laporan Keuangan tersebut setidak-tidaknya meliputi Laporan Realisasi APBD, Neraca, Laporan Arus Kas dan Catatan Atas Laporan Keuangan yang dilampiri dengan laporan keuangan perusahaan daerah (Nordiawan, 2006: 34). dari laporan keuangan yang diterbitkan pemerintah daerah dapat dijadikan indikator bahwa peningkatan pertumbuhan ekonomi yang bersumber dari pendapatan asli daerah (PAD) dapat memberikan kinerja keuangan yang baik.

Penelitian yang dilakukan oleh Mulia dan Basri (2016), pendapatan asli daerah berpengaruh signifikan terhadap kinerja keuangan daerah Artinya bahwa tingginya penerimaan pendapatan asli daerah dapat meningkatkan kemandirian pemerintah daerah sehingga hal tersebut berimplikasi pada kinerja keuangan pemerintah daerah. Pada sisi lain penelitian yang dilakukan Mulyani dan Wibowo (2017) mendapatkan hasil bahwa pendapatan asli daerah berpengaruh negatif signifikan terhadap kinerja keuangan pemerintah daerah yang 
memberikan indikasi bahwa peningkatan pendapatan asli daerah dapat menurunkan kinerja keuangan pemerintah daerah.

\subsubsection{Pengaruh dana alokasi umum (DAU) terhadap kinerja keuangan daerah}

Hasil dalam penelitian ini menunjukan dana alokasi umum (DAU) berpengaruh positif signifikan terhadap kinerja keuangan daerah artinya dana alokasi umum merupakan dana yang bersumber dari pendapatan APBN yang dialokasikan dengan tujuan pemerataan kemampuan keuangan antar daerah untuk mendanai kebutuhan daerah dalam rangka pelaksanaan desentralisasi, semakin besar dana yang diterima oleh daerah dari pusat akan memberikan tingkat kinerja yang semakin baik. Dana Alokasi Umum adalah dana perimbangan dan bersumber dari pendapatan APBN yang dialokasikan dengan tujuan pemerataan kemampuan keuangan antar daerah untuk mendanai kebutuhan daerah dalam rangka pelaksanaan Desentralisasi. DAU sebagai salah satu elemen desentralisasi fiskal menjadi elemen penting bagi pemerintah daerah untuk menutup pembiayaaan daerah implikasinya, DAU dialokasikan kepada setiap daerah dalam rangka menjalankan kewenangan pemerintah daerah dalam memberikan pelayanan publik kepada masyarakat. DAU yang merupakan transfer pemerintah pusat kepada daerah bersifat "block grant", yang berarti daerah diberi keleluasaan dalam penggunaannya sesuai dengan prioritas dan kebutuhan daerah dengan tujuan untuk menyeimbangkan kemampuan keuangan antar daerah.

$$
\text { Dalam Teori stewardship }
$$

mengasumsikan hubungan yang kiat antara keberhasilan tujuan organisasi dengan kepuasan prinsipal. Steward akan melindungi dan memaksimalkan keuntungan yang dapat diperoleh organisasi dengan memaksimalkan kinerja perusahaan, sehingga dengan demikian fungsi utilitas ikut maksimal dengan sendirinya. Asumsi penting dari stewardship adalah manajer membentuk tujuannya agar sesuai dengan tujuan prinsipal. Namun, tidak berarti steward tidak memiliki kebutuhan hidup. Pengelolaan keuangan daerah dinyatakan bahwa hasil dari kegiatan yang telah dicapai sehubungan dengan penggunaan anggaran dengan kuantitas dan kualitas yang terukur dan tingkat pencapaian pelaksanaan suatu program organisasi dalam mewujudkan tujuan organisasi, keputusan pelanggan, serta kontribusinya terhadap perkembangan ekonomi masyarakat. Kemandirian keuangan daerah sendiri ditunjukan oleh besar kecilnya pendapatan asli daerah dibandingkan dengan pendapatan daerah yang berasal dari sumber lain misalnya, bantuan pemerintah pusat ataupun dari pinjaman. Dari beberapa pendapat yang dikemukakan diatas, dapat disimpulkan bahwa kemandirian keuangan daerah adalah kemampuan pemerintah daerah dalam menggali dan mengelola sumber daya atau potensi daerah yang dimilikinya secara efektif dan efisien sebagai sunber utama keuangan daerah yang berguna untuk membiayai kegiatan penyelenggaraan pemerintah daerah.

Penelitian yang dilakukan oleh Faisal dan Nofrianto (2016), menemukan bahwa dana alokasi umum berpengaruh positif signifikan terhadap kinerja keuangan pemerintah daerah. sunaryo dan Gofar (2015), menemukan bahwa dana alokasi umum tidak berpengaruh positif signifikan terhadap kinerja keuangan pemerintah daerah.

\subsubsection{Pengawasan terhadap kinerja keuangan daerah}

Hasil dalam penelitian ini menunjukkan bahwa pengawasan berpengaruh positif signifikan terhadap kinerja keuangan daerah. Secara umum pengawasan dapat dirumuskan sebagai suatu proses kegiatan yang dilakukan secara terus menerus untuk mengamati, memahami dan menilai setiap 
pelaksanaan kegiatan tertentu sehingga dapat mencegah atau memperbaiki kesalahan atau penyimpangan yang terjadi. Pengawasan keuangan daerah berkaitan erat dengan kinerja pemerintah daerah. Hal ini disebabkan karena pencapaian keberhasilan suatu visi dan misi membutuhkan pengawasan yang baik dan maksimal, baik dalam segi perencanaan, penganggaran dan pelaksanaan kegiatan yang telah direncanakan sebelumnya. Semakin baik tingkat pengawasan pengelolaan keuangan daerah maka akan menghasilkan kinerja pemerintah yang baik pula.

Wiguna et al (2015) penelitiannya mengatakan bahwa dengan adanya Pelaksanaan pengawasan keuangan daerah yang baik akan mendorong pemerintah untuk melaksanakan kegiatan yang efektif, efisien, akuntabel dan transparan dalam upaya mewujudkan pelaksanaan pemerintah yang baik. Dengan demikian, semakin baik pengawasan keuangan daerah maka akan semakin baik pula kinerja pemerintah daerah. Hasil penelitian ini menunjukan bahwa pemerintah Kabupaten Bengkalis memiliki nilai rata-rata tertinggi selama 5 tahunan dengan nilai 88.5 dibandingkan dengan Kab/Kota yang ada di propinsi Riau. Hal ini berarti dengan adanya pengawasan langsung yang dilakukan oleh pihak Inspektorat dalam melaksanakan tugas dan tanggung jawabnya seperti mengawasi kegiatan atau program pemerintah, melakukan financial audit terhadap laporan keuangan dalam upaya mengevaluasi kinerja. Hasil penelitian ini sejalan dengan penelitian Widanarto (2009) dan Wiguna et al (2015) yang menunjukan bahwa pengawasan pengelolaan keuangan daerah berpengaruh signifikan terhadap kinerja pemerintah daerah.

Dalam penelitian ini sejalan dengan penelitian yang dilakukan oleh Fahmi dan Addirfa (2015) memberikan hasil pengawasan berpengaruh positif signifikan terhadap kinerja keuangan daerah. Sejalan dengan hasil penelitian yang dilakukan oleh Irawan (2014), bahwa pengawasan berpengaruh positif signifikan terhadap kinerja keuangan daerah.

\subsubsection{Pengawasan dapat memoderasi belanja modal dalam meningkatkan kinerja keuangan daerah}

Hasil dalam penelitian ini menunjukan pengawasan dapat memoderasi belanja modal dalam meningkatkan kinerja keuangan daerah artinya pengawasan keuangan daerah berkaitan erat dengan kinerja pemerintah daerah. Hal ini disebabkan karena pencapaian keberhasilan suatu visi dan misi membutuhkan pengawasan yang baik dan maksimal, baik dalam segi perencanaan, penganggaran, dan pelaksanaan kegiatan yang telah direncanakan sebelumnya. Pengawasan keuangan daerah merupakan bagian integral dari pengelolaan keuangan daerah yang pada dasarnya mencakup segala tindakan untuk menjamin agar pengelolaan keuangan daerah berjalan sesuai dengan rencana, ketentuan, dan undang-undang yang berlaku. Semakin baik tingkat pengawasan pengelolaan keuangan daerah maka akan menghasilkan kinerja pemerintah yang baik pula.

Dalam teori stewardshipdalam penelitian ini yaitu stewards dalam hal ini adalah para pengelola anggaran diharapkan akan bekerja dengan sebaikbaiknya untuk kepentingan principal yaitu masyarakat dan instansi mereka sehingga suatu oragnisasi dapat 
dipercaya untuk bertindak sesuai dengan kepentingan publik dengan melaksanakan tugas dan fungsinya dengan tepat, merencanakan dan melaksanakan anggaranyang diamanahkan kepadanya, dengan demikian tujuan pengelolaan anggarandapat tercapai secara maksimal. Pengawasan internal dan eksternal berpengaruh cukup kuat secara bersamasama terhadap kinerja pemerintah (widarnato, 2017). Belanja modal merupakan anggaran pemerintah daerah untuk memperoleh asset dalam peningkatan pelayanan publik, dalam konteks pengelolaan daerah dan pengalokasian belanja modal sangat berkaitan dengan fungsi pengawasan yang dilakukan demi tercapainya tujuan kesejahteraan masyarakatnya. Kinerja keuangan daerah yang baik apabila pencapaian kinerja tersebut sesuai dengan apa yang direncanakan dan sesuai apa yang menjadi target sejak awal. Peran Inspektorat dalam melakukan pengawasan terhadap belanja modal daerah akan berpengaruh signifikan terhadap proses berjalannya kegiatan pembangunan ekonomi menuju kesejahteraan masyarakat, sehingga kinerja keuangan daerah mengalami pertumbuhan yang signifikan juga.

Penelitian yang dilakukan oleh Fahmi dan Addirfa (2015) memberikan hasil pengawasan berpengaruh positif signifikan terhadap kinerja keuangan daerah. Sejalan dengan hasil penelitian yang dilakukan oleh Irawan (2014), bahwa pengawasan berpengaruh positif signifikan terhadap kinerja keuangan daerah.

\subsubsection{Pengawasan dapat memoderasi pendapatan asli daerah (PAD) dalam meningkatkan kinerja keuangan daerah}

Hasil dalam penelitian ini menunjukan pengawasan dapat memoderasi pendapatan asli daerah (PAD) dalam meningkatkan kinerja keuangan daerah artinya pengawasan daerah yang dilakukan oleh Inspektorat merupakan bagian integral yang mencakup tindakan untuk menjamin pengelolaan keuangan daerah berjalan sesuai dengan rencana ketentuan dan UU yang berlaku. Semakin baik pengawasan terhadap sumber pendapatan asli daerah (PAD) maka akan menghasilkan kinerja keuangan daerah yang baik pula.

UU No.33 tahun 2004 pasal 6 menjelaskan bahwa PAD terdiri dari pajak daerah, retribusi daerah, hasil pengelolaan kekayaan daerah, dan lainlain pendapatan asli daerah yang sah. Teori Stewardship, model of man diasumsikan sebagai seorang yang memiliki perilaku dimana dia dapat dibentuk agar selalu dapat diajak bekerjasama dalam organisasi, memiliki perilaku kolektif atau berkelompok dengan utilitas tinggi daripada individunya dan selalu bersedia untuk melayani. Pada teori stewardship terdapat suatu pilihan antara perilaku self-serving dan pro-organisational. Yang mana perilaku manajer tidak akan dipisahkan dari kepentingan organisasi juga bahwa perilaku eksekutif disejajarkan dengan kepentingan prinsipal dimana para steward berada. Steward akan menggantikan atau mengalihkan selfserving untuk berperilaku kooperatif. Sehingga meskipun kepentingan antara steward dan prinsipal tidak sama, steward tetap akan menjunjung tinggi nilai kebersamaan. Sebab steward berpedoman bahwa terdapat utilitas yang lebih besar pada perilaku kooperatif, dan perilaku tersebut dianggap perilaku rasional yang dapat diterima.

Baik-buruknya pemerintahan bisa dinilai bila ia telah bersinggungan dengan semua unsur prinsip-prinsip good governance. Keuangan daerah adalah semua hak dan kewajiban daerah dalam rangka penyelenggaraan pemerintahan daerah yang dapat dinilai dengan uang termasuk didalamnya segala bentuk kekayaan yang berhubungan dengan hak dan kewajiban daerah tersebut dalam kerangka APBD (Bab 1, Pasal 1, Ayat 5 Peraturan Pemerintah No. 58 Tahun 2005). Kinerja keuangan pemerintah 
daerah adalah tingkat pencapaian dari suatu hasil kerja di bidang keuangan daerah yang meliputi peneriman dan belanja daerah dengan menggunakan sistem keuangan yang ditentukan melalui suatu kebijakan atau ketentuan perundang-undangan selama satu periode anggaran. Bentuk dari pengukuran kinerja tersebut berupa rasio keuangan yang terbentuk dari sistem laporan pertanggungjawaban daerah berupa perhitungan APBD.

Penelitian yang dilakukan oleh Suqri dan Mardiamal (2016) memberikan hasil pengawasan mampu memoderasi pengaruh belanja modal terhadap kinerja keuangan daerah secara positif signifikan. Sejalan dengan hasil penelitian yang dilakukan oleh Arivonda (2015), bahwa GGG memperkuat hubungan belanja modal terhadap kinerja keuangan daerah.

\subsubsection{Pengawasan dapat memoderasi dana alokasi umum (DAU) dalam meningkatkan kinerja keuangan daerah}

Hasil dalam penelitian ini menunjukan pengawasan dapat memoderasi dana alokasi umum (DAU) dalam meningkatkan kinerja keuangan daerah. Menurut UU no.33 tahun 2004 tentang perimbangan keuangan pusat dan daerah, menjelaskan bahwa dana alokasi umum (DAU) adalah dana yang bersumber dari pendapatan APBN yang dialokasikan dengan tujuan pemerataan kemampuan keuangan antar daerah untuk mendanai kebutuhan daerah dalam rangka pelaksanaan desentralisasi. Perimbangan keuangan menjelaskan bahwa jumlah keseluruhan DAU ditetapkan sekurang-kurangnya $26 \%$ dari pendapatan dalam negeri netto yang ditetapkan oleh APBN. Pemerintah daerah saat ini masih banyak membutuhkan dana bantuan dari pemerintah pusat untuk meningkatkan sarana dan prasarana publik serta infrastruktur dalam meningkatkan pembangunan daerah yang bertujuan peningkatan pelayanan dan kesejahteraan masyarakat yang semakin baik sehingga dapat disimpulkan jika dana alokasi umumnya tinggi maka perlu dilakukan pengawasan. Konsekuensi dalam peningkatan DAU adalah bertambahnya tanggung jawab daerah atas berbagai tugas dan tanggung jawab dalam pengelolaan keuangan daerah. Dalam pengelolaan keuangan daerah perlu adanya kontrol terhadap penggunaan anggaran di daerah ini karena merupakan suatu persoalan yang sangat penting untuk dilaksanakan dan mekanisme kontrol yang jelas sangat diperlukan untuk menilai kelayakan pengeluaran daerah dikaitkan dengan kepentingan masyarakat yang bersangkutan.

Daerah dapat memakai dana transfer yang berupa bantuan DAU yang digunakan untuk penyediaan fasilitas dan pelayanan terbaik yang dikelola secara penuh oleh pemerintah daerah sesuai dengan kebutuhan. Semakin besar DAU yang diberikan dari pusat maka pengawasan terhadap pengelolaan keuangannya juga harus semakin baik demi tercapainya tujuan kesejahteraan masyarakat, sehingga pertumbuhan ekonomi di daerah tersebut juga mengalami peningkatan yang dilihat dari kinerja keuangan daerah tersebut. Pengawasan anggaran meliputi seluruh siklus anggaran, mulai dari tahap perencanan, pelaksanaan, maupun pertangungjawaban. Secara sederhana pengawasan anggaran merupakan proses pengawasan terhadap kesesuaian perencanan anggaran dan pelaksanaanya dalam melaksanakan pembangunan daerah. Pengawasan terhadap pelaksanaan perlu dilakukan, hal ini bertujuan untuk memastikan seluruh kebijakan publik yang terkait dengan siklus anggaran dilaksanakan sesuai dengan peraturan perundang-undangan yang berlaku dan berorientasi pada prioritas publik.

Penelitian yang dilakukan oleh Ferdinand (2016) memberikan hasil GGG memperkuat hubungan dana alokasi umum terhadap kinerja keuangan daerah. Sejalan dengan hasil penelitian 
yang dilakukan oleh Zea dan Akmal (2015), bahwa pengawasan mampu memoderasi pengaruh dana alokasi umum terhadap kinerja keuangan daerah secara positif signifikan.

\section{KESIMPULAN DAN SARAN}

\subsection{Kesimpulan}

Berdasarkan hasil penelitian dan pembahasan yang telah dilakukan terhadap kinerja keuangan daerah, maka dapat disimpulkan sebagai berikut:

1. Hasil penelitian ini menemukan bahwa belanja modal berpengaruh positif signifikan terhadap kinerja keuangan daerah. Hal ini berarti meningkatnya belanja modal suatu daerah yang tercermin dalam peningkatan asset investasi seperti asset tanah, infrastruktur dan asset lainnya untuk kepentingan fasilitas publik sehingga berpengaruh positif terhadap kinerja keuangan di daerah.

2. Hasil penelitian ini menemukan bahwa pendapatan asli daerah (PAD) berpengaruh positif signifikan terhadap kinerja keuangan daerah. Hal ini berarti meningkatnya PAD yang terlihat meningkatnya pendapatan dari pajak daerah, distribusi dan laba usaha daerah sehingga meningkatnya pertumbuhan ekonomi.

Meningkatnya pertumbuhan ekonomi daerah akan mensejahterakan masyarakat sehingga terciptanya masyarakat yang produktif dalam usaha yang diiringi dengan kinerja keuangan daerah yang meningkat juga.

3. Hasil penelitian ini menemukan bahwa dana alokasi umum (DAU) berpengaruh positif signifikan terhadap kinerja keuangan. Hal ini berarti meningkatnya dana alokasi umum yang dialokasikan bertujuan untuk pemerataan kemampuan keuangan daerah untuk mendanai setiap kebutuhan daerah dalam rangka pelaksanaan disentralisasi akan meningkatkan kinerja keuangan didaerah.

4. Hasil penelitian ini menemukan

bahwa pengawasan berpengaruh positif signifikan terhadap kinerja keuangan. Hal ini berarti bahwa meningkatnya pengawasan yang dilakukan inspektorat terhadap kegiatan pemerintah daerah dalam pengembangan pembangunan sumber daya didaerah nya maka akan meningkatkan kinerja keuangan daerah yang semakin baik.

5. Hasil penelitian ini menemukan bahwa pengawasan dapat memoderasi antara belanja modal dan kinerja keuangan daerah. Hal ini berarti meningkatnya pengawasan terhadap belanja modal daerah yang dilakukan Inspektorat maka realisasi belanja modal di suatu daerah akan berjalan sesuai dengan anggaran yang diharapkan, sehingga kinerja keuangan yang telah ditetapkan akan tercapai.

6. Hasil penelitian ini menemukan bahwa pengawasan dapat memoderasi antara pendapatan asli daerah (PAD) dan kinerja keuangan daerah. Hal ini berarti meningkatnya pengawasan dari inspektorat akan memberikan motivasi pemerintah daerah untuk bekerja demi kesejahteraan masyarakatnya sehingga pertumbuhan ekonomi di daerahnya akan meningkat juga, seiring dengan kinerja keuangan yang baik.

7. Hasil penelitian ini menemukan bahwa pengawasan dapat memoderasi antara dana alokasi umum (DAU) dan kinerja keuangan daerah. Hal ini berarti meningkatnya pengawasan dari inspektorat daerah untuk mengawasi dana yang ditransfer pusat benar-benar akan dialokasikan demi kebutuhan fasilitas masyarakatnya sehingga kesejahteraan dan pertumbuhan ekonomi daerah juga akan meningkat seiring dengan kinerja keuangan daerah yang baik.

\subsection{Saran}


1 Penelitian ini masih ada keterbatasan mengenai sampel yang dilakukan pada wilayah kabupaten/kota di propinsi Riau selama tahun 20142018, yang sebaiknya menggunakan seluruh kabupaten/kota se-Indonesia agar hasilnya dapat lebih digeneralisasi, kemudian jangka waktu pengamatannya lebih terupdate sehingga untuk penelitian selanjutnya dapat menggambarkan situasi dan kondisi saat ini..

2 Penelitian ini adalah untuk mengukur tingkat kemandirian kinerja keuangan daerah di propinsi Riau selama pelaksanaan otonomi daerah, sehingga diharapkan pada penelitian selanjutnya dapat membandingkan dua indikator kinerja keuangan daerah tersebut sebelum dan sesudah otonomi daerah.

\section{DAFTAR PUSTAKA}

Abdullah, Syukriy. 2013. Analisis Kinerja Keuangan Pemerintah Daerah.

Adisasmita, Rahardjo. 2015. "Pengelolaan Pendapatan Dan Anggran Daerah". Graha Ilmu: Yogjakarta.

Abdullah, S., \& Halim, A. (2014). The study of capital expenditures in local government budgets in relation to maintenance spending and sources of income. Jurnal Akuntansi Pemerintah, 2, 17-32

Anthony, R.N., \& Govindarajan, V. (2017). Management control systems, (12 th Edition). McGraw-Hill London Balitbang Provinsi NTT. (2016). Analysis of the efficiency and effectiveness of government spending on regional

Ghozali, Imam. 2016. “Aplikasi Analisis Multivariate dengan Program IBM SPSS

Peraturan Pemerintah. Peraturan Pemerintah Republik Indonesia Nomor 58 Tahun 2005 Tentang Pengelolaan Keuangan Daerah.

Undang-Undang Republik Indonesia Nomor 09 Tahun 2015 Tentang Pemerintah Daerah.

Rohman, Abdul. 2017. "Pengaruh Peran Manajerial Pengelola Keuangan dan Fungsi Pemeriksaan Intern terhadap Kinerja Pemerintah Daerah (Survei pada Pemda Kota, Kabupaten, dan Provinsi di Jawa Tengah)". Jurnal MAKSI,Vol 7,no. 2:206220. Agustus.

Sukmawan, dan Anggarsari. 2016. "Pengaruh Pengawasan Intern Dan Pelaksanaan Sistem Akuntansi Keuangan Daerah Terhadap Kinerja Pemerintah Daerah (Survei pada Satuan Kerja Perangkat Daerah Kota Tasikmalaya)".Jurnal Akuntansi Fakultas Ekonomi unsil, vol.4,no. 1.

Tuasikal, Askam. 2015. "Pengaruh Pengawasan, Pemahaman Sistem akuntansi Keuangan dan Pengelolaan Keuangan Terhadap Kinerja Unit Satuan Kerja Pemerintah Daerah". Universitas 
Pattimura Ambon. Vol. 10, No.Juni. Hlm. 66-88.

Widanarto, Agustinus. 2009. Pengaruh Pengawasan Internal dan Pengawasan Eksternal Terhadap Kinerja Pemerintah Kota Bandung. Bandung: Fakultas Ilmu Sosial dan Ilmu Politik Universitas Padjadjaran.

Wiguna, Made BS., Yuniartha G., dan Darmawan N. 2015. Pengaruh Pengawasan
Keuangan Daerah, Akuntabilitas Dan Transparansi Pengelolaan Keuangan Daerah Terhadap Kinerja Pemerintah Daerah Kabupaten Buleleng, eJournal Vol. 3 No. 1. 